\begin{tabular}{|c|c|}
\hline 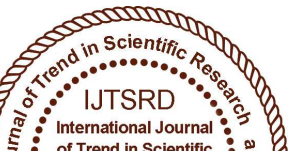 & $\begin{array}{l}\text { International Journal of Trend in Scientific } \\
\text { Research and Development (IJTSRD) }\end{array}$ \\
\hline 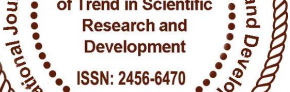 & International Open Access Journal \\
\hline 000 & ISSN No: 2456 - 6470 | www.ijtsrd.com | Volume - 2 | Issue - 3 \\
\hline
\end{tabular}

\title{
Non-Formal Educational Resources and The Employability Impact of Youths in The South-West Region of Cameroon
}

\author{
Emefua Rose. M.Ed. \\ Ph.D, Fellow, Department of Educational Foundations and \\ Administration, University of Buea, Cameroon
}

\section{ABSTRACT}

This study titled, "The impact of the resources of nonformal education and employability of youths in the South-West Region of Cameroon", is based on the problem of employability of youths. The general objective is to study the relationship between the impact of the resources of non-formal education and employability of youths. The following theories supported the study: Self Efficacy Theory, Human Capital Theory, Parsons Theory and Experiential Learning Theory. Four research questions emerged from analyzing the problem as follows: what is the relationship between the pedagogy of the resources of non-formal education and employability of youths? What is the relationship between the curriculum of non-formal education and employability of youths? What is the relationship between the use of didactic materials in the resources of non-formal education sector and employability of youths? What is the relationship between the practical process in the resources of non-formal education sector and employability of youths? From these questions, four hypotheses were formulated. Being a quantitative study, the descriptive survey research design was used. The target population constituted 480 students/apprentices in the South-West Region of Cameroon. 210 students/apprentices from Fako, Meme and Ndian Divisions were sampled to represent the population. A questionnaire on non-formal education and employability of youths was used to collect data. The spearman's Rho correlation coefficient was used to test hypotheses at a 0.05 level of significance. The chi square was used to compare the proportions for significance difference. The findings reveal that pedagogy (0.568), curriculum
(0.620), use of didactic materials (0.680) and practical process $(0.701)$ have a significant positive effect on the employability of youths from non-formal education. From the study four hypotheses were formulated. It was therefore concluded that pedagogy, curriculum, didactic materials and practical process have a significant role in the employability of youths and must not be neglected. The following recommendations were made according to objectives: according to objective One, In-service training should be provided for the trainers of non-formal education sectors, Certificates should be awarded at the end of non-formal education course. For objective two, there should be harmonization of the curriculum of the resources of non-formal education; the appropriate policy (laws) should be formulated that will govern the non-formal education sector. For objective three, taxes should be reduced for those carrying out the resources of non-formal education activities; financial and material support should be given to nongovernmental organizations carrying out the resources of non-formal education activities. For objective four, financial motivation should be given to the apprentices so that they will be regular at the workshops.

Keywords: Non-Formal Educational Resources, Employability Impact, Youths, South-West Region of Cameroon

\section{INTRODUCTION}

Education is widely considered to be an imperative for employability; it is increasingly evident that the problem of functional literacy and employability 
particularly in developing countries needs to be addressed by the creation of a flexible educational system. (Taylor 2006). According to Fonkeng (2010), more than $1 / 3$ of all daily movements are related to education. Non-formal education can be understood as an organized educational process which takes place alongside mainstream systems of education and training and does not typically lead to certification; individuals participate on voluntary basis. It is set up to serve young people who are charged with operational structures which are democratic and nongovernmental. According to Coombs (1973), nonformal education is "any organized programme of learning carried on outside the frame work, rules and logistic of the formal education system". Paulson (2011) defines non-formal education "as structure, systematic, non school, educational and training activities of relatively short duration in which sponsoring agencies seek concrete behavioural changes in fairly distinct target population". Employability is defined as "a set of attributes, skills, and knowledge that all labour market participants should possess to ensure they have the capacity of being effective in the workplace to the benefit of themselves, their employers and the wider economy (Yorke, 2004). Employability can also be defined as the possession by an individual of the qualities and competences required to meet the changing needs of employers and customers and thereby help to realize their potentials in work.

During the pre-colonial period in Cameroon, education was somehow non formal. The purpose was immediate integration of the child into the society and the preparation for a responsible adult life. This was the process whereby children learnt by socializing, doing practical things around the homes and villages as well as participating in ceremonies, farming, fishing, hunting, carving, cooking, etc. This type of non formal education was naturally relevant to the needs of the society and the demand of the environment, where hunting was important for the survival of the community; involuntary training was related to such skills. The education produced honest, respectable, skilled, cooperative individuals who conform to the norms of the community (Fonkeng, 2010). But with the coming of the missionaries in 1844 , a new system of education was introduced, The formal system of education. Cameroon today is on the threshold of an important stage in its educational development after a bitter experience of the economic crisis (Fonkeng 2010). That is the education related to the realities of the society in terms of the development of technological skills, resources and job creation. It is from this point that non-formal education has become a prerequisite for employment, job creation, self-reliance and economic growth of the country (President Biya's speech to the Youths, 2016). The researcher wanted to find out the impact of non-formal education and the employability of youths in terms of its pedagogy, curriculum, didactic materials and the practical process in that sector in order to meet vision 2035. The study aimed at finding out the impact of non-formal education and the employability of youths in the South West Region.

\section{Background of the Study}

Non-formal education became part of the internal discourse on education policy in the late 1960s and early 1970s as Fordham (1993) relates in 1967 at an international conference in Washington (U.S.A). Ideas were set out for what was to become a widely read analysis of the growing world education crisis (Coombs, 1968). There were concerns about unsuitable curricular, a realization that educational growth and economic growth were not necessarily in step, and that jobs did not emerge directly as a result of educational inputs; many countries were finding it difficult (politically and economically) to pay for the expansion of formal education. The conclusion was that educational systems had adapted too slowly to the socio-economic changes around them and that they were held back not only by their own conservation but also by the inertia of societies themselves. If we also accept that educational policy making trends to follow rather than lead other social trends, then it followed that change would have to come not merely from within formal schooling but from the wider society and from other sectors within it. It was from this point of departure that planners and economists in the World Bank began to make a distinction between informal, non-formal and formal education (Fordham, 1993). Informal Education was truly a lifelong process whereby every individual acquires attitudes, values, skills, and knowledge from daily experiences and the educative influences and resources in his/her environment from family and neighbours, from work and play, from the market place, the library and mass media.

Non-Formal Education was any organized educational activity outside the established formal system whether operating separately or as an important feature of some broader activity that is intended to serve identifiable learning clienteles and learning objectives. The distinction made was largely 
administrative. Formal education is linked with schools, training institutions, non-formal with community groups and other organizations and the informal covers what is left, example interactions with friends, families, work and colleagues (Coombs and Ahmed, 1974). The problem with this is that people often organize educational events as part of their everyday experiences and these definitions do not imply hard and fast categories. In particular, there may be some overlaps and confusion between the informal and non-formal.

Non-Formal Education in Africa developed from a number of strands, including mass literacy programmes and community development starting from the Jeanes schools in the East and Central Africa between the wars, and evolving into broader programs associating education with other community development activities. In addition to this, history included the strand of agricultural extension (Thompson, 1981). This connected history from the background to the development of both non formal and community development and participation in both Southern countries and Northern industrialized countries.

In Cameroon and Africa as a whole, non-formal education existed before the first contact with the Whiteman. The purpose was immediate integration of children into the society and preparation for $a$ responsible life. The process of this type of education was children learnt by socializing, doing practical things around the homes as well as participating in ceremonies, farming, fishing, hunting, cooking, and carving and so on (Fonkeng, 2010). The nature of the indigenous education was naturally relevant to the needs of the society and the demands of the environment. For example, where fishing was important for the survival of the community, involuntary training was related to such skills, which developed the strength of the youth and tuned his reflexes to the stimuli of the environment. The youth practiced activities and related occupations, receiving necessary orientation in this domain, to render them resourceful and effective members of the community (Fonkeng, 2010).

The intellectual training was vocational training or the process of learning a craft such as hunting, weaving, welding, pottery, carving, carpentry, wine tapping, etc. This was in the non-formal way because there was no planned curriculum for these activities. From this view point, it is evident that before the arrival of the Whiteman, Africans as well as Cameroonians were conscious and concerned about their way of life and process of training but just that it was not formal. With the coming of Whiteman the Cameroonian system of education (modern and formal) was preoccupied with issues that are irrelevant and have no potentials for developing the people and rendering them functionally literate in mathematics, reading, writing and ecology (Fonkeng, 2010). But for the Cameroon nation to emerge by 2035, with education that is meaningful and efficient, and for youths to gain employment, non-formal education should be encouraged. This type of system gave birth to the nonformal education sector in Cameroon. Even though Cameroon lacked a well-developed system of adult education in the late $1990 \mathrm{~s}$, nonetheless, at that time, recommendations were being made to develop new trade or change of jobs.

Understanding what constitutes non-formal education is an important first step for managing policies and programmes as well as national education systems. Currently, there is no single universally accepted definition of non-formal education (Schmida, 2009). Instead, many existing definitions simply contrast it with formal education, adopting a tripartite categorization of education - Formal, non-formal, and informald (Coombs and Ahmed, 1973). This categorization is still widely used for the purposes of planning, administration, financing, monitoring and evaluation. While the notion of non-formal education is based on the 1973 definition, Coombs and Ahmed are still influential in practice. Experts and educationalists have conceptualized non-formal education reflecting, changing educational landscapes and understanding of "learning".

Some have moved away from the single counter positioning of non-formal education and formal education, by which non-formal education tends to be treated as inferior to the latter (Robinson -Pant, 2014). Others claim that boundaries between formal and non-formal education are blurred (Farrell and Hartwell, 2008). Another view point among those who focus on "situated learning" holds that the tripartite categorization of education should be abandoned, conceiving "formality" and "informality" as attributes present in all circumstances of learning (Colly, Hodkinson and Malcolm, 2003). There are also those who recognize the breadth and richness of knowledge, skills, attitudes and values acquired outside school, and argue for a perception of learning as a continuum of informal self-directed, non- formal 
and formal learning (Rogers, 2004).To express "nonformal education" or "a form of it", different terms are used such as "flexible learning", "alternative learning", "complementary learning", "supplementary education", "second chance education" and "extracurricular activities". Due to the concept's vagueness, some even advocate using descriptions of each framework, rather than attempting to arrive at common definition (Bhola, 1983).

The concept of non-formal education is yet to be crystallized. Consensus is however, available on its definition structure. It has meant different things to different people. According to Coombs, it refers to "any organized programme of learning carried on outside the framework, rules, and logistic of formal education system". Paulson defines it, "as structure, systematic, non school, educational and training activities of relatively short duration in which sponsoring agencies seek concrete behavioural changes in fairly, distinct target populations. McCall considers "the entire range of learning experiences outside of regular graded school system", as nonformal education. Non-formal education, though a negative descriptor, is to be distinguished from formal education on one hand and informal or incidental education on the other. It is certainly "non incidental" and "non school" education carried on outside school system. But it has a definite programme.

\section{Statement of the Problem}

Education is a top priority of the state of Cameroon. This can be confirmed from the budget of 2014 by law number 2014/026 of Dec. 2013 financial year. The budget of Basic Education, Secondary Education and Higher Education is slightly higher than those of other ministries but what bothers the researcher is employability of youths after all the expenditure. The researcher has observed that despite the existence of all the learning institutions and many universities, students graduate with diplomas and other academic qualifications and some cannot pick up jobs. The government spends these huge sums of money on the training of teachers, paying their salaries, providing didactic or instructional materials and so on and students end up without employment. After all this expenditure by the state, if youths do not gain employment, the problem is waste of educational resources and finances by the state. This leads to psychological torture on the part of the youths because what was learned in school has no value and they become consumers and a liability to their parents. Some of these youths involve themselves in criminal acts such as drug addiction, delinquent acts, armed robbery, and so on.

The statistics of the competitive entrance into GHTTTC Kumba for the 2015/2016 session shows that about one thousand four hundred (1400) candidates registered in the South West Region alone. This confirmed the fact that some youths graduate from schools and cannot gain employment. This has given room to the non-formal education sector where many youths are using as a short way for selfemployment. Without gainful employment there is no productivity and consequently no social, economic, nor technical development. Many graduates from Universities are seen to evolve to non-formal education structures as they tend to think that this is an easy outlet to job acquisition. Due to the increasing notion that no-formal education was due to high rate of school dropout, the poor and the less privileged, the researcher therefore intends to find out if pedagogy, curriculum, didactic or instructional materials, and the practical process in the non-formal education sector affects the employability of youths.

\section{Specific Objectives}

To find out if pedagogy used in the non-formal education sector has an impact on the employability of youths.

To investigate the relationship between the curriculum of non-formal education sector and employability of youths?

To determine the relationship between the use of didactic materials (instructional materials) in nonformal education sector and employability of youths.

To analyse the relationship between the practical process used in the non-formal education sector and employability of youths.

\section{Specific Research Questions}

$>$ What is the relationship between the pedagogy of non-formal education sector and employability of youths?

$>$ What is the relationship between the curriculum of the non-formal education sector and employability of youths?

$>$ What is the relationship between the use of didactic materials (instructional materials) in the non-formal education sector and employability of youths?

What is the relationship between the practical process in the non-formal education sector and employability of youths? 


\section{Theoretical Perspectives for The Study}

\section{The Theory of Self Efficacy (Bandura, 1995)}

Albert Bandura is best known for his theory of selfefficacy and his work in social learning, including the "Bobo doll" experiment. He propounded the theory in 1995. The self-construct characteristics of selfconfidence enable the individual to have a positive, realistic view of themselves or institutions they find themselves. The self-efficacy theory refers to the individual's expectation of the ability to achieve an influential factor in ensuring personal potentials realized (Steven, 2005). This theory suggests that a person who is high in self confidence has a pragmatic view of themselves and their abilities which gives them resolutions in their endeavours.

According to Bandura (1995), "perceived selfefficacy refers to the beliefs in ones capabilities to organize and execute the course of action required to manage perspective situations". It influences how people think, feel, motivate themselves and act. He further suggests that there are several sources of efficacy beliefs relevant to employability; they are mastery experiences, vicarious experiences provided by social models and social persuasion. The theory of self-efficacy has a pivotal role to play in the nonformal education sector because the non-formal education sector is done voluntarily by individuals who want to be self-reliant or be job creators. Also, the theory will help the youths in the non- formal sector to have self-confidence, have a pragmatic view of themselves and the abilities to achieve what is expected of them.

Another point is that, self-efficacy will help the nonformal education instructor in the teaching of the youths because with his experiences he/she will give many opportunities to youths to try particular tasks themselves during practical's. For example

$>$ Mastery Experiences which are the most effective way of creating a strong sense of self efficacy and so play a vital role within employability (Bandura, 1995).

$>$ Vicarious Learning will help youths to decide, after viewing the actions of others, what type of actions will be effective for their own performance of a task.

> With Social Persuasion, youths are convinced that they possess the capabilities needed to succeed in a particular activity. This encourages them to put in more efforts and stay motivated in order to achieve success Bandura, (1995).
From the above mentioned points, it can be presumed from Bandura's work that by providing the opportunities for learning of mastery experiences, vicarious experiences, social persuasion and evaluation of these experiences, self-efficacy can be increased. A graduate who believes he/she do whatever is necessary is far more likely to gain a position and be successful in whatever occupations he/she chose than a graduate who does not have selfbelief, self-efficacy as a sub set of employability skills; meta skills can enable the students to expand and support the ranges or other skills they have developed. There is an understanding that reflections is a key graduate skill that can contribute to employability, the belief that employability of students will be enhanced by their ability to reflect on their own learning. Knight and Yorke (2003b), describe employability as being a blend of selfconfidence and Meta cognition, which includes the student's ability to be reflective about their own progress.

\section{The Human Capital Theory (Becker, 1964)}

The theory of human capital was generated in the work of Becker (1964), and rests on the assumption of a strong relationship between productivity and wages. The model of Ben Porath (1967) and the famous Mincer equation (1974), show that education and training strongly influence wages formation during the life cycle. In the economic perspective, according to the theory of human capital, education and training are treated as an investment process which generates a future flow of income. Investment in education is assumed to exert a positive impact on worker's productivity and in turn on their income. Apart from these benefits, investing in human capital also incurs cost. This cost can take the form of expenses of studying (fees, cost of accommodation, etc) but also include opportunity cost that is from the loss to potential income during study. The time spent on studying cannot be devoted to a productive job that generates production and income (Marshall, 1998). It is assumed this cost are compensated when the knowledge and competences accumulated in education process (human capital) generate a sufficient high rate of returns and raise the future flow of income to a level high enough to compensate for all cost incurred (Mincer, J. 1991).

Human capital theory is very vital for the non-formal education sector and employability of youths. The investment in the non-formal education sector is expected to generate future income when youths are 
employed. When investment is done on youths a positive impact on productivity and in turn benefits a high income wage in future. Also, the human capital theory enables the youths to know that there is cost to be incurred in the non-formal sector and the cost is compensated with the knowledge and competences gained during the period in school (Mbua, 2003).

The formulation by Friedman and Kuznets (1945) and the significant development of the theory by Becker (1962 - 1964) and Mincer (1958, 1962) provided a novel view of the life cycle of earnings by linking it to the time profile of investment in human capital; people make most of their investment in themselves when they are young and to a large extent by forgoing current earnings. The essence of human capital theory to non-formal educator sector is that investment is done on youths at the early age and to have positive returns earnings at the later time in life. The knowledge put forth by Ben Porath (1964), is that investment is undertaken mostly by the youth, that they have a longer period over which they will receive returns on their investments. This idea stimulates the youths in non-formal education sector to know that they will receive returns for their investment done in school. It will also encourage the youths to know that they have to participate in the creation of their own human capital by using their own abilities, innate or acquired, the quality of cooperating inputs, the constraints and opportunities offered by the institutional setup. The most commonly used measures of human capital are schooling and work experience (Mincer, 1991).

\section{Parson's Theory (1908)}

Frank Parsons developed the idea of matching careers to talents, skills and personality. He explained that people perform best when they are in jobs best suited to their abilities. Frank (1908) was regarded as the founder of the vocational guidance movement. He developed talent matching approach which was later developed into the trait and factor theory of occupational choice. At the centre of parson's theory is the concept of matching. Parson states that occupational decision making occurs when people achieve:

An accurate understanding of their individual traits (aptitudes, interests, personal abilities).

A knowledge of jobs and the labour market.

$>$ Rational and objective judgment about the relationship between their individual traits and the labour market.
The knowledge of Parson's theory will enable the youths in the non-formal education sector to understand their individual traits, interest, personal abilities about the jobs and the labour market in which they will work. They will develop the idea of matching what they like as career to their talent, their skills that they have learnt and the personality that they have. The traits and factor theory operates under the premise that it is possible to measure both individual talents and the attitudes required in particular jobs. In his book, "choosing a vocation" (1909), Parson maintains that personal counsellor is fundamental to career search. In particular, he wrote seven stages for career counsellor to work through with the clients.

Personal Data: Create a statement of a key fact about the person, remembering to include every fact that has bearing on the vocational problem. This state will help the youths either in school or when they are employed to take note of all the necessary aspects at the job sites and to write down facts that can easily be forgotten in a book.

Self-Analysis: A self-analysis is done in private and under the instruction of the counsellor. Here the youths in the non-formal education sector will be able to check themselves whether they are following the norms of the job market. This will enable them to correct where they go wrong.

The Client's Own Choice and Decision: The counsellor must bear in mind that the choice of the vocation should be made by the clients. Also, the youths will make a choice of what job or occupation they will like to do alone without any Person's Influence.

The Outlook of the Vocational Field: The counsellor should be familiar with industries knowledge such as lists and classification of industries and vocation. This stage will enable the youths to understand that they must work with the guidance or the counsellor who will be able to know how many industries need workers and their locations.

> Induction and Advice: A broad minded attitude coupled with logical and clear reasoning are critical at this stage.

> General Help Fullness: The counsellor helps the clients to fit into the chosen work and to reflect on the decision. The good aspect of Parson's theory is that it still guides career counselling today though it is without criticism; matching assumes a degree of stability with the labour market. However, the reality is that the market volatility 
means individuals must be prepared to change and adapt to their circumstances.

\section{Non formal Education and Informal Learning Practices and Employability}

The study recognition of non-formal and informal learning practices was carried out by Patrick Werguin in 2010. The target population was 30 countries while the sample size was 22 countries and the data collected was quantitative data. The findings from some of the countries were: Germany has arrangements for exemption to enable people to enter vocational education on the basis of recognized nonformal and informal learning outcomes. Decrees on the regulation of adult learning published in Belgium (Flemish community) between 1999 and 2007 enable the measurement and assessment of acquired competences to be used in particular to shorten subsequent training.

In Hungary, the recognition of non-formal and informal learning outcomes really began at the local levels in the 1990s with the creation of nine recognition centres which drew from French and Canadian experience (with skills appraisaland learning portfolios in France and visits from PLAR experts and formularization with concept of recognition in the case of Canada)

Australia also offers a good example of an approach derived from the concept of learning regions which was based on the idea of networking organization with numerous partnership. This provides for cross fertilization through the exchange of the ideas and practices. In Australia, the clear aim of this kind of approach was to act in the interest of people who are socially disadvantaged.

In Spain, the economic changes of the last decades have meant that greater flexibility is now expected of learning and qualifications systems. Spain is given though to a possible policy framework for the recognition of non-formal and informal learning outcomes, as symbol of this greater flexibility. This has been under consideration since 2000 and the memorandum on lifelong learning.

In Ireland, in general, there is no indication given in the certificate awarded on successful completion of a recognized programme of how the learning has been achieved (whether formal, non-formal or informal). This accord with the requirements of diploma supplement and the certificate supplement.
The United Kingdom has had a national qualifications framework since 1997. It has been subjected to criticisms on the grounds that it could be more transparent, more consistent, less bureaucratic and easier to follow. In short, it should be closer to the need of the employers and members of the public.

In Chile, there is no national qualification framework but this is being discussed, as Chile is seeking to establish one. Nine sectors of activity-including fisheries, gas, electricity, wine growing, mining and tourism-are at the heart of concerns about qualifications. But the recognition of non-formal and informal learning outcomes has not been taken into account in the qualifications systems, which was not based on learning outcomes.

The Netherlands has sectoral agreements because the recognition of non-formal and informal learning outcomes are seen as potentially capable of stimulating continuing training. The recognition of these outcomes are not an end in itself, but a means of eventually making good progress through the longterm development of individual and their human capital.

Greece appears to fear skills shortages in pioneering professional sectors such as new information and communication technology of foreign languages. It would seem that the recognition of non-formal and informal learning outcomes should quickly get under way there. The experience in Austria appears more positive. Number of stigma seems to be attached to the recognition of non-formal and informal learning outcomes, even though qualifications obtained in the formal systems are the most in demand. From the experience of Slovenia, one can appreciate the difficulty of the task and the time that will be needed to complete it.

In South Africa, the limited capacity of the current educational and training systems are struggling to find solutions to the large scale nature of the problems of access and recognition. Most of those who require these opportunities do not have the resources to pay for them and so bursaries and massive state funding would be needed to make them possible.

\section{Research Methodology}

This study was based on the descriptive survey design. A survey research design consists of collecting data from defined population using a sampled population to describe the variables or issues under study (Mbua, 2003). Descriptive studies are 
usually the best methods for collecting information that will demonstrate relationships and describe the world as it exists. Bickman and Rog (1998) suggest that descriptive studies can answer questions such as "what is" and "what was". The main aim was to describe the data and characteristic about what was being studied. The idea behind was to study frequencies, averages and other statistical calculations. In the survey method research, the participants answer questions administered through the questionnaires. After the participants answer the questions, the researcher describes the responses given. In order for the survey to be both reliable and valid, the questions were conducted properly. Questions were clear and easy to comprehend. Closeended questions were given and are easy to analyse statistically, but they limit the responses that participants can give while open-ended questions were also given and allow for a greater variety of responses from participants but are difficult to analyse statistically because the data must be coded or reduced in some manner.

\section{Sample and Sampling Techniques}

A sample is a collection of some elements of a population or a subset of the population chosen by the researcher to represent the entire population. In this study, 480 students/ apprentices were taken from government, parastatals, non-governmental organizations and apprenticeship centres from Fako, Meme, Ndian, Manyu, KupeManengouba and Libialem divisions of the South-West Region to represent the target population.

Table 1: Sample Distribution of Students/apprentices in the Non-Formal Education Sector

\begin{tabular}{|c|c|c|c|}
\hline Division & Non-Formal Education Sectors & No of Students & Sample size \\
\hline \multirow[t]{7}{*}{ Fako } & SAR & 20 & 20 \\
\hline & Women Empowerment & 12 & 12 \\
\hline & Youth animation & 20 & 20 \\
\hline & earpentry ional Journ & all $\quad 13$ & 13 \\
\hline & Tailoring & 13 & 13 \\
\hline & 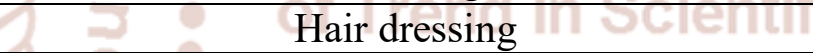 & C 13 & 13 \\
\hline & Motor mechanics $\mathrm{ch}$ and & 09 & 09 \\
\hline Total & 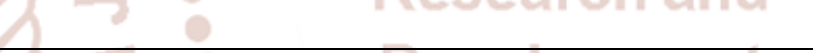 & 100 & 100 \\
\hline \multirow[t]{8}{*}{ Meme } & Community development centres & 15 & 15 \\
\hline & Multi-Purpose Youth Centre & 15 & 15 \\
\hline & Women empowerment centres 170 & $\mathbf{1 0}$ & 10 \\
\hline & SAR & $10 \square$ & 10 \\
\hline & Carpentry & 05 & 05 \\
\hline & Tailoring & 05 & 05 \\
\hline & Hair dressing & 05 & 05 \\
\hline & Motor mechanics & 05 & 05 \\
\hline Total & Whangaras & $\mathbf{7 0}$ & 70 \\
\hline \multirow[t]{7}{*}{ Indian } & Women empowerment family & 07 & 07 \\
\hline & SAR & 13 & 13 \\
\hline & Carpentry & 04 & 04 \\
\hline & Hair dressing & 04 & 04 \\
\hline & Tailoring & 04 & 04 \\
\hline & Motor mechanics & 02 & 02 \\
\hline & Grand Total & $\begin{array}{c}40 \\
210\end{array}$ & $\begin{array}{c}40 \\
210\end{array}$ \\
\hline
\end{tabular}

In order to select the sample (480) students/apprentices needed for this study, the researcher used simple random and purposive sampling to get the schools and students.

\section{Reliability of the Instrument}

Reliability concerns the consistency with which an instrument measures what it was intended for. Reliability of the questionnaire is ensured when the response represents some consistency. The researcher used the test and 
retest method. Five (05) copies of the questionnaires were administered to the part of the population of some youth who were not included in the sample of study in the non-formal education and the result was recorded. After two weeks the same questionnaires were administered to the same respondents and the results were again recorded; since the results of the both were the same, it was concluded that the responses were consistent and the instrument was reliable.

Table 2: Reliability analysis for the pre-testing of instrument

\begin{tabular}{|l|l|l|l|l|}
\hline \multicolumn{1}{|c|}{ Conceptual component } & \multicolumn{1}{|c|}{ Cronbach's Alpha } & Variance & $\mathbf{N}_{\text {cases }}$ & \multicolumn{1}{|c|}{$\mathbf{N}_{\text {item }}$} \\
\hline Pedagogy & $\mathbf{0 . 9 8 5}$ & $\mathbf{0 . 0 0 0}$ & $\mathbf{2 0}$ & $\mathbf{8}$ \\
\hline Curriculum & $\mathbf{0 . 9 6 8}$ & $\mathbf{0 . 0 0 0}$ & $\mathbf{2 0}$ & $\mathbf{1 1}$ \\
\hline Use of didactic materials & $\mathbf{0 . 9 7 0}$ & $\mathbf{0 . 0 0 0}$ & $\mathbf{2 0}$ & $\mathbf{9}$ \\
\hline Practical process & $\mathbf{0 . 9 5 8}$ & $\mathbf{0 . 0 0 0}$ & $\mathbf{2 0}$ & 7 \\
\hline Employability of youth & $\mathbf{0 . 9 8 5}$ & $\mathbf{0 . 0 0 0}$ & $\mathbf{2 0}$ & $\mathbf{1 2}$ \\
\hline Integrated Value Mapping (IVM) & $\mathbf{0 . 9 9 1}$ & $\mathbf{0 . 0 0 0}$ & $\mathbf{2 0}$ & $\mathbf{4 7}$ \\
\hline
\end{tabular}

From the table above the table the findings of the pre-testing of instruments of non-formal education shows that the conceptual components did not violate the cronbach alpha of 0.05 and variance of 0.000 .

Table 3: Reliability analysis for final study

\begin{tabular}{|l|l|l|l|l|}
\hline \multicolumn{1}{|c|}{ Conceptual component } & \multicolumn{1}{|c|}{ Cronbach's Alpha } & Variance & $\mathbf{N}_{\text {cases }}$ & \multicolumn{1}{|c|}{$\mathbf{N}_{\text {item }}$} \\
\hline Pedagogy & $\mathbf{0 . 9 8 5}$ & $\mathbf{0 . 0 0 0}$ & $\mathbf{2 1 0}$ & $\mathbf{8}$ \\
\hline Curriculum & $\mathbf{0 . 9 6 8}$ & $\mathbf{0 . 0 0 0}$ & $\mathbf{2 1 0}$ & $\mathbf{1 1}$ \\
\hline Use of didactic materials & $\mathbf{0 . 9 7 0}$ & $\mathbf{0 . 0 0 0}$ & $\mathbf{2 1 0}$ & $\mathbf{9}$ \\
\hline Practical process & $\mathbf{0 . 9 5 8}$ & $\mathbf{0 . 0 0 0}$ & $\mathbf{2 1 0}$ & $\mathbf{7}$ \\
\hline Employability of youth & $\mathbf{0 . 9 8 5}$ & $\mathbf{0 . 0 0 0}$ & $\mathbf{2 1 0}$ & $\mathbf{1 2}$ \\
\hline IVM & $\mathbf{0 . 9 9 1}$ & $\mathbf{0 . 0 0 0}$ & $\mathbf{2 1 0}$ & $\mathbf{4 7}$ \\
\hline
\end{tabular}

For both the pre-testing phase of the instrument and the final study, the internal consistency assumption was not violated for any of the conceptual components and all the Alpha values were close to perfect reliability. The trainees were highly homogenous in their characteristics given that the values of the variance are all very close to 0 .

Table4: Test of Normality

\begin{tabular}{|l|l|l|l|l|l|c|}
\hline & \multicolumn{3}{|c|}{ Kolmogorov-Smirnov } & \multicolumn{3}{c|}{ Shapiro-Wilk } \\
\hline & Statistic & $\mathrm{df}$ & Sig. & Statistic & Df & Sig. \\
\hline Pedagogy & .179 & 197 & .000 & .917 & 197 & .000 \\
\hline Curriculum & .122 & 197 & .000 & .939 & 197 & .000 \\
\hline Use of didactic material & .206 & 197 & .000 & .891 & 197 & .000 \\
\hline Practical process & .168 & 197 & .000 & .900 & 197 & .000 \\
\hline Employability of youth & .155 & 197 & .000 & .902 & 197 & .000 \\
\hline
\end{tabular}

Chi-Square test was used to appraise the association between the indicators under study and the socio demographic or background indicators. Data were presented using frequency table, charts, code-groundingquotation table and conceptual diagram. All statistics will be presented at the 95\% Confidence Level (CL), Alpha $=0.05$.

\section{Findings}

Research Question One: To find out if pedagogy used in the non-formal education sector has an impact on the employability of youths. 
Table 5: Students' Opinions on the Pedagogy of Non-Formal Educational Sector.

\begin{tabular}{|l|l|l|l|}
\hline \multicolumn{1}{|c|}{ Pedagogy } & \multicolumn{1}{|c|}{ Agree } & \multicolumn{1}{|c|}{ Disagree } & \multicolumn{1}{|l|}{} \\
\hline 1. Our teacher is always the first person in school. & $\mathbf{9 9 . 5 \% ( 2 0 9 )}$ & $\mathbf{0 . 5 \% ( 1 )}$ & $\mathbf{2 1 0}$ \\
\hline 2. Our teacher is a professional. & $\mathbf{9 9 . 5 \% ( 2 0 9 )}$ & $\mathbf{0 . 5 \% ( 1 )}$ & $\mathbf{2 1 0}$ \\
\hline $\begin{array}{l}\text { 3. Our teacher always asks us questions at the end of an } \\
\text { activity. }\end{array}$ & $\mathbf{9 9 . 5 \% ( 2 0 9 )}$ & $\mathbf{0 . 5 \% ( 1 )}$ & $\mathbf{2 1 0}$ \\
\hline 4. Our teacher always gives us work in groups. & $\mathbf{9 9 . 5 \% ( 2 0 9 )}$ & $\mathbf{0 . 5 \% ( 1 )}$ & $\mathbf{2 1 0}$ \\
\hline 5. All practical works are evaluated & $\mathbf{9 9 . 5 \% ( 2 0 9 )}$ & $\mathbf{0 . 5 \% ( 1 )}$ & $\mathbf{2 1 0}$ \\
\hline 6. Our teacher always corrects us where we go wrong. & $\mathbf{9 9 . 5 \% ( 2 0 9 )}$ & $\mathbf{0 . 5 \% ( 1 )}$ & $\mathbf{2 1 0}$ \\
\hline 7. I understand my teacher during his/her lesson. & $\mathbf{9 9 . 5 \% ( 2 0 9 )}$ & $\mathbf{0 . 5 \% ( 1 )}$ & $\mathbf{2 1 0}$ \\
\hline 8. All internships are evaluated. & $\mathbf{9 9 . 5 \% ( 2 0 9 )}$ & $\mathbf{0 . 5 \% ( 1 )}$ & $\mathbf{2 1 0}$ \\
\hline Multiple Response Set (MRS) & $\mathbf{9 9 . 5 \% ( 1 6 7 2}$ & $\mathbf{0 . 5 \% ( 8 )}$ & $\mathbf{1 6 8 0}$ \\
\hline
\end{tabular}

Research question Two: To investigate whether the curriculum used in the non-formal education sector has an impact on the employability of youths.

Table 6: Item by Item Analysis of Students' and Apprentices' Perception on Curriculum of Non-Formal Education Sector

\begin{tabular}{|l|l|l|l|l|}
\hline No & \multicolumn{1}{|c|}{ Curriculum } & \multicolumn{1}{|c|}{ Agree } & Disagree & \multicolumn{1}{|c|}{ N } \\
\hline 9 & Our teacher always orientates us during the first week & $\mathbf{9 9 . 5 \% ( 2 0 9 )}$ & $\mathbf{. 5 \% ( 1 )}$ & $\mathbf{2 1 0}$ \\
\hline 10 & Our school programme includes practical activity & $\mathbf{9 9 . 5 \% ( 2 0 9 )}$ & $\mathbf{. 5 \% ( 1 )}$ & $\mathbf{2 1 0}$ \\
\hline 11 & Our teacher always plans what we will do for the term & $\mathbf{9 9 . 5 \% ( 2 0 9 )}$ & $\mathbf{. 5 \% ( 1 )}$ & $\mathbf{2 1 0}$ \\
\hline 12 & Our teacher tells us the strategy to be used & $\mathbf{9 9 . 5 \% ( 2 0 9 )}$ & $\mathbf{. 5 \% ( 1 )}$ & $\mathbf{2 1 0}$ \\
\hline 13 & We always market our products rend in & $\mathbf{9 9 . 5 \% ( 2 0 9 )}$ & $\mathbf{. 5 \% ( 1 )}$ & $\mathbf{2 1 0}$ \\
\hline 14 & Our teacher always schedules time for every activity & $\mathbf{9 9 . 0 \% ( 2 0 8 )}$ & $\mathbf{1 . 0 \% ( 2 )}$ & $\mathbf{2 1 0}$ \\
\hline 15 & Our teacher always monitors our activities rC an & $\mathbf{9 9 . 0 \% ( 2 0 8 )}$ & $\mathbf{1 . 0 \% ( 2 )}$ & $\mathbf{2 1 0}$ \\
\hline 16 & $\begin{array}{l}\text { Our teacher always communicates us when he will not } \\
\text { be there }\end{array}$ & $\mathbf{9 8 . 6 \% ( 2 0 7 )}$ & $\mathbf{1 . 4 \% ( 3 )}$ & $\mathbf{2 1 0}$ \\
\hline 17 & Our teacher always goes for seminar workshops & $\mathbf{9 8 . 6 \% ( 2 0 7 )}$ & $\mathbf{1 . 4 \% ( 3 )}$ & $\mathbf{2 1 0}$ \\
\hline 18 & Our teacher always evaluates our materials & $\mathbf{9 9 . 0 \% ( 2 0 8 )}$ & $\mathbf{1 . 0 \% ( 2 )}$ & $\mathbf{2 1 0}$ \\
\hline 19 & We have more practical activities than theory & $\mathbf{9 9 . 0 \% ( 2 0 8 )}$ & $\mathbf{1 . 0 \% ( 2 )}$ & $\mathbf{2 1 0}$ \\
\hline & Multiple response set (MRS) & $\mathbf{9 9 . 2 \% ( 2 2 9 1}$ & $\mathbf{. 8 \% ( 1 9 )}$ & $\mathbf{2 3 1 0}$ \\
\hline
\end{tabular}

Research Question Three: To Determine Whether the Use of Didactic Materials (Instructional Materials) in Non-Formal Education Sector has an Impact on the Employability of Youths.

Table 7: Item by item analysis of students' and apprentices' perception on the use of didactic materials of non-formal education sector

\begin{tabular}{|l|l|l|l|l|}
\hline No & \multicolumn{1}{|c|}{ Didactic materials } & \multicolumn{1}{|c|}{ Agree } & \multicolumn{1}{|c|}{ Disagree } & \multicolumn{1}{|c|}{ N } \\
\hline 20 & Our teacher always uses learning tools for demonstration & $\mathbf{9 9 . 0 \% ( 2 0 8 )}$ & $\mathbf{1 . 0 \% ( 2 )}$ & $\mathbf{2 1 0}$ \\
\hline 21 & Our teacher always uses visual materials. & $\mathbf{9 9 . 0 \% ( 2 0 8 )}$ & $\mathbf{1 . 0 \% ( 2 )}$ & $\mathbf{2 1 0}$ \\
\hline 22 & Our school has a computer, planning and sewing machines & $\mathbf{9 8 . 6 \% ( 2 0 7 )}$ & $\mathbf{1 . 4 \% ( 3 )}$ & $\mathbf{2 1 0}$ \\
\hline 23 & Our teacher always shows us how to manipulate materials & $\mathbf{9 9 . 0 \% ( 2 0 8 )}$ & $\mathbf{1 . 0 \% ( 2 )}$ & $\mathbf{2 1 0}$ \\
\hline 24 & Every student/apprentice has his/her tools & $\mathbf{9 8 . 6 \% ( 2 0 7 )}$ & $\mathbf{1 . 4 \% ( 3 )}$ & $\mathbf{2 1 0}$ \\
\hline 25 & $\begin{array}{l}\text { We always discover new things when we uses our } \\
\text { materials }\end{array}$ & $\mathbf{9 8 . 1 \% ( 2 0 6 )}$ & $\mathbf{1 . 9 \% ( 4 )}$ & $\mathbf{2 1 0}$ \\
\hline 26 & We use materials to be creative & $\mathbf{9 9 . 0 \% ( 2 0 8 )}$ & $\mathbf{1 . 0 \% ( 2 )}$ & $\mathbf{2 1 0}$ \\
\hline 27 & We use our materials to design different things & $\mathbf{9 8 . 1 \% ( 2 0 6 )}$ & $\mathbf{1 . 9 \% ( 4 )}$ & $\mathbf{2 1 0}$ \\
\hline 28 & We have adequate material for teaching & $\mathbf{9 8 . 6 \% ( 2 0 7 )}$ & $\mathbf{1 . 4 \% ( 3 )}$ & $\mathbf{2 1 0}$ \\
\hline & Multiple response set (MRS) & $\mathbf{9 8 . 7 \% ( 1 8 6 5}$ & $\mathbf{1 . 3 \% ( 2 5 )}$ & $\mathbf{1 8 9 0}$ \\
\hline
\end{tabular}


International Journal of Trend in Scientific Research and Development (IJTSRD) ISSN: 2456-6470

Research Question Four: To analyze whether the practical process used in the non-formal education sector has an impact in the employability of youths.

\section{Table 8: Item by item analysis of students' and apprentices' perception on the practical process of non-} formal education sector

\begin{tabular}{|c|c|c|c|c|}
\hline & & Agree & Disagree & $\mathbf{N}$ \\
\hline 29 & The area where we do our practicals is spacious & $98.6 \%(207)$ & $1.4 \%(3)$ & 210 \\
\hline 30 & Rules are given to us during the practicals & $98.6 \%(207)$ & $1.4 \%(3)$ & 210 \\
\hline 31 & We observe our teacher carefully during demonstration & $99.0 \%(208)$ & $1.0 \%(2)$ & 210 \\
\hline 32 & Tasks are assigned to us by our teacher. & $99.0 \%(208)$ & $1.0 \%(2)$ & 210 \\
\hline 33 & We also undertake internship. & $98.6 \%(207)$ & $1.4 \%(3)$ & 210 \\
\hline 34 & We always perform tasks instructed by our teacher. & $98.1 \%(206)$ & $1.9 \%(4)$ & 210 \\
\hline \multirow[t]{2}{*}{35} & We have some work in enterprises. & $98.6 \%(207)$ & $1.4 \%(3)$ & 210 \\
\hline & Multiple response set (MRS) & $98.6 \%(1450$ & $1.4 \%(20)$ & 1470 \\
\hline
\end{tabular}

\section{Discussions}

Results also reveal that items 5,6 and 8, which were intended to find out if practical work are evaluated, if teacher correct students and if all internship are evaluated had the highest percentage of $99.5 \%$. This means that the greater the pedagogy of non-formal education in the South -West Region the higher the employment level of youths. This affirms Entwhistle (1996) who agrees that assessment affects how students study, encouraging them to make a deep approach to a task rather than a surface approach. He also states that assessment criteria inform students of what they need to improve upon to succeed and identify what their tutor perceives to be important and what is not (LTSN Genenic Centre, 2002). Knight (2001) was also inline that feedback can be emotionally important, particularly when it builds learners' confidence and sense of achievement and offer suggestions how improvements could be made next time. This clearly supports the fact that pedagogy of non-formal education is effective thus giving the students the ability to put into practice what they have learnt from their teacher which will be needed in the enterprise.

Comparing the average percentage of items under the use of didactic materials $(98.7 \%)$ to that of items under employability of youth $(98.8 \%)$, resulted to the fact that the relationship between the two variables is positive as confirmed by the results of the third hypothesis test on table $25(\mathrm{r}=0.680 ; \mathrm{P}=0.000)$. This result ties with what Mzaka (1989) argued that teaching aids in the classroom makes learning real, practical and fun through seeing, hearing, discovering and doing. He explained that seeing what things look like and how they work is more interesting than only reading about them. He therefore advocated that didactic materials should be used in discovering, asking and doing things and seeing, hearing and discussing them will make learning existing more meaningful and lasting.

Looking closely to the work of Fina (2008), she stressed that the use of didactic materials in the nonformal education positively influences the quality of educational process, develops knowledge and skills of the students in pedagogic issues, intensifies the motivation and creative activity of students and forms positive attitudes for them. This confirms the results of items 15, 17 and 23, where students strongly accepted that their teachers always used didactic materials for demonstration, that they have materials like computers, planning, sewing machines, etc and that they have adequate materials; it can be deduced that the use of didactic materials will make the students have quality and effective skills which is the key for employment.

Results obtained showed that, like other indicators of non-formal education, practical process has a high positive relationship with employability of youths. This result was obtained when the average percentage of practical process $(98.6 \%)$ was compared with that of employability of youth (98.8\%) and was confirmed by the results of the fourth hypothesis test on table 33 $(\mathrm{r}=0.701 ; \mathrm{P}=0.000)$. The result agrees with that of Nomikoum (1985) who investigated on the practical process of non-formal education and found that nonformal education gives young people the possibility to develop their values, skills and competences other than the one developed in the framework of formal education. Those skills include a wide range of competences such as interpersonal, organizational, conflict management, leadership, planning, co- 
ordination, and practical problem solving skills, team work, self-confidence, discipline and responsibility.

\section{Recommendations}

$>$ The findings of objective one review that pedagogy of non-formation education has a positive impact on employability of youths. In service training should be organized by the state for those carrying out non-formal education activities, certificates should be awarded to students/apprentices at the end of their course.

$>$ From the findings of objective two, it can be noted that the curriculum of non-formal education has a part to play on employability of youths. Thus trainers of each specialty should harmonize their curriculum in such a way that a specialty in Buea (tailoring) will have the same curriculum with tailoring in Kumba.

$>$ Furthermore, the findings of objective three review that the use of didactic materials in the non-formal education sector employability of youths was eminent. From this accession, the researcher recommend that trainers and students must have their own didactic materials, the government give subsidies to trainers of non-formal education activities through the ministry of labour and employment who will identify those concern.

$>$ In addition findings from objective four review that the practical process in the non-formal education sector has a positive linear relationship with employability of youths. The researcher recommend that taxes should be reduced for those involved in the practical process. This will help to improve the practical process.

\section{Concluding Remarks}

To conclude, it should be noted that non-formal education is a reality of employability. This is a great assurance from a study carried out on the recognition of non-formal education practices by Nwerguin in 2010. In Hungary, the recognition of non-formal education outcomes began at the local levels in the 1990s with the creation of nine recognition centres which draw from French and Canadian experience. To prove that non-formal education creates employment, it became an international discourse or issue since the early 1960s. Another conference was held in 1999 and agreed on the following: That government and appropriate authorities of member states should recognize non-formal education as a de facto partner in the lifelong process, and support financially (grants, tax reductions, provide official buildings or training centres, publish their activities in catalogue of good practice) etc.

More so, non-formal education is very important in Europe because it bridges the gap between the mismatch in Europe and ensures that the young are able to transition from education to employment. According to Nomikoum (1985), the project manager of non-formal education book in AEGEE Europe pointed out that non-formal education gives young people the possibility to develop their values, skills and competences other than the ones developed in framework of formal education.

Another international conference was held in Dakar 2000 , its aims being to reaffirm its commitment to ensuring universal access to basic education of high quality by the year 2015 .

In Africa, non-formal education is timidly recognized despite the efforts made by the government. It has taken a parallel trend with minimal integration and no systematic mechanism to equate and document learning that occurs outside the formal system, hence making people despise non-formal education. The 1999 evaluation report of the FAL programme indicates that many participants drop out and complain of lack of accreditation and recognition of the learning they get through this programme, thus denying them access to life improving opportunities and continuing education.

Cameroon lacked a well-developed system of nonformal education in the late 1990s. Nonetheless, at that time recommendations were made to develop new educational opportunities for adults seeking, to upgrade their skills, learn a new trade or change jobs. Currently in Cameroon, many people especially the youths are aware of the importance of non-formal education. This is why students graduate from formal education and move to workshops in order to gain skills which are needed in the job market. This can be confirmed by the result on table 11 on the background about the qualification of apprentices /students. A majority of them have graduated from primary, secondary, high school and universities.

From Lovett's point of view(1994), the term nonformal education has been applied to industrialized countries particularly in context or work with groups who have been disadvantaged in terms of economics, social and educational opportunities (including the unemployed women and ethnic groups who have suffered discrimination) as part of strategies to 
combat poverty. This view point is in conformity with the qualification table of the respondents. It revealed that 133 respondents had the first school leaving certificate. This implies that most youths who are in the non-formal education sector are the disadvantaged. The result of the indicators of the independent variable (pedagogy, curriculum, didactic materials and practical process) reveals that non formal education plays a vital role in the employment of youths in the South-West Region. The practical process was the top (0.701), seconded by didactic materials (0.680), thirdly curriculum (0.620), followed by pedagogy with (0.568). Still, from the thematic analysis of the specialties, respondent opinions show that they like their specialty that they are doing because it will enable them to have jobs. In addition, twelve specialties (tailoring, hair dressing, commercial activities, agriculture, accounting, hotel management, computer, motor mechanic, home economics, building construction, electricity, and wood work were sampled which represented the nonformal education sector.

\section{References}

1) Amin, M, E. (2005). Social science research: conception, methodology and analysis. Kampula: Makerere University Printery.

2) Atkins, M.J. (1999). Oven ready and self-basting: talking stock of employability skills. Teaching in higher Education 4(2) 267-280.

3) Becker, G. (1964). Human capital: A Theoretical and Empirical Analysis, with Special Reference to Education. New York: Columbia University Press.

4) Colley, Hodkinson \& Malcontn (2003). Informal and formally in Learning. London: Learning and Skills Research Centres.

5) Coombs, P. H \& Ahmed, M. (1974). Attacking Rural Poverty. How Non- Formal Education can Help. Baltimore: John Hopkins University Press.

6) Coombs and Ahmed (1973). Attacking Rural Poverty. Baltimore: The John Hopkins University Press.

7) Coombs (1968). The World Educational Crisis. New York: Oxford University Press.

8) Coombs, (1973). New Paths Learning for Rural Children and Youth ES Sex, Conn.USA: International Council for Education Development.
9) Council of Europe (2003). Recommendation Rec (2003) 8 of the committee of ministers to member states on the promotion and Recognition of nonformal Education/ Learning of young people. Strasburg.

10) Council of Europe (2001). Symposium on NonFormal Education. Strasburg (EYC) 13-15 October 2000. Report (sympo/Edu (2000) rap).

11) Hillage, J and Pollard, E (1998). Employability. Developing a framework for Policy analysis. Research Brief 85, Department for Education and employment.

12) Hopper (2007). Integrating formal and non-formal Education. A policy case study from Uganda: Paris; II E P.ion Basic

13) Islam, $M$ and Mia, A (2007). The innovative elements in non-formal education of Bangladesh: Perspective of income generating programmes for poverty alleviation. International Journal of Education and Development using information and communication technology, 3 (3) 89-104.

14) Lent, T. W, Brown. S.D, Hackett, G (2000). Contextual support and Barriers to Career Choices; A Social Cognitive analysis Journal of Counselling Psychology, 47, 1.36-49.

15) Little, B. (2001). Reading between the lines of graduate employment. Quality in higher Education: 7(2) 121-129. Learning Unit 2, London. YMCA George William College. LTSN Generic Centre 16 October 2002.

16) Maharasoa M. and Hay. D (2001). Higher education and graduate employment in South Africa. Quality in higher Education. 7(2) 139147.

17) Mbua (2003). Educational Administration. Theory and Practice. The management of organization and individuals. Cameroon. Design house Limbe.

18) Mincer, J. (1958). Investment in human capital and personal income Distribution. Journal of

19) Ololube N.P. (2011). Education and social: An interactive approach. Owerr; Springfield publishers.

20) Ololube et al: (2012 a). Assessing the Role and Function of ITS Training and Development and policy implementation a public Sector organization. 
International Journal of Trend in Scientific Research and Development (IJTSRD) ISSN: 2456-6470

21) Ololube (2009).Understanding Teachers Professional Competences For Education Effectiveness. Owerri: Spring field publishers.

22) Ololube, N.P. (2006). Teacher Education, school effectiveness and Improvement. A study of Academic and professional Qualification on Teachers Job Effectiveness in Nigeria Secondary Schools. Doctor Dissertation, University of Helsinki, Faculty of Behavioural Sciences, Department of Applied sciences of Education, Helsinki: University of Helsinki Press.

23) Openjuru G. (2004). Adult literacy and development links. A perspective from a non literate's literacy practices and environment.

24) Romer (1990). Endogenous Technological change. Journal of political Economy 98 (5), 71102 .

25) Romi and Schmida (2009). Non-formal education: A major Educational force in the post modern era. Cambridge Journal of Education Vol. 39 No L June, 2009, Pp 257-273, Rout ledge.

26) Rosen H.S. (1999). Public Finance. New York; McGraw-Hill.

27) Sands et al (1995). A statewide exploration of the nature and use of curriculum in special education, exceptional children 62 (1), 68-63.

28) Schultz (1992).The Economic Value of Education Studies into the economics of education. Elgar books Aldrishot.

29) Taylor, E.W. (2006).Making meaning of local Non-formal education: Practitioner's perspective. Adult Education Quarterly 56 (4), 291-307.
30) Thompson, A.R. (1981). Education and Development in Africa. London: The Macmillan Press. Ltd.

31) Tight (1996). Key Concepts in Adult Education and Training. London: Rutledge.

32) Treasury H.M (2000). Productivity in the UK: The Evidence and the Government's approach: London. UK Treasury.

33) UNESCO (1972). Learning to be (prepared by Faure et al) Paris. UNESCO.

34) UNESCO (2012). Guide lines on the Recognition, Validation and accreditation of the outcomes of non-formal education and informal learning UNESC. Paris.

35) UNESCO (2010).Gender equality, Education and training. Retrieved April 27, 2012 from http//www un.org/women watch/Beijing 15/online Education discussion.

36) UNESCO (2006a). Recommitting to Adult education and learning Adult education and development 61,7-18. Retrieved April 21, 2012 from http//www. Eaea.org/doc/dvv/61.

37) Wanjie (2011). Challenges facing non-formal education in Kenya. Retrieved April 10.2012 from http//wisdomnestblogspot. Com/2011/07/ challenges-facing non-formal education $\mathrm{html}$.

38) William, K.T. Larry. J. and Scott WG (1995). Automotive Encyclopaedia. U.S.A. The good heart willcox company. Inc.

39) Yasunaga M: and Tambo (2014). UNESCO. File oosc-2014 Non-formal Education. 